\title{
OPINIÃO
}

\section{O Campeonato Mundial da Ciência ${ }^{69}$}

Renato Dagnino*

O número de artigos de brasileiros que aparecem nas 10 mil melhores revistas que constituem a base considerada para o campeonato cresceu 56\% no último ano.

O país agora ocupa a $13^{a}$ colocação no ranking. Sem querer estragar prazeres dos que festejam a notícia, vale recomendar moderação: o número de revistas brasileiras que integram a base passou de 63, em 2007, para 103, em 2008 (conforme o artigo "Inusitado aumento da produção científica", de Rogério Meneghini, publicado neste espaço na última terça).

Os mais otimistas dizem que, com 30 mil artigos (2,12\% do total mundial), estamos próximos da Coréia, um posto acima, com 35 mil. Um país que, por usar sua ciência para fazer tecnologia e desenvolver a economia, estaria nos mostrando o caminho que vai dos artigos ao bem-estar social.

Mas há setores da comunidade de pesquisa que questionam o significado disso que é visto como o Campeonato Mundial da Ciência, no qual os artigos publicados nas revistas em que se joga o jogo são os gols marcados pelos cientistas-jogadores. Quase todas essas revistas, aliás, em países desenvolvidos.

Os questionamentos podem ser entendidos como associados a outros quatro campeonatos.

O primeiro, interno ao "campo" da ciência, sugere que o Campeonato da Ciência Publicada é a "segunda divisão". A primeira seria o Campeonato da Ciência Citada. Nele, o gol não é o número de artigos publicados, mas o número de vezes que ele é citado.

Dizem os críticos: os artigos de brasileiros são citados bem abaixo da média mundial, e estimativas mostram que a superioridade coreana nesse campeonato é de quase 3 para 1.

O segundo questionamento avança para o Campeonato da Tecnologia. Os gols, aqui, são as patentes depositadas nos EUA. Os artilheiros, diferentemente do que ocorre lá, não

\footnotetext{
${ }^{69}$ Publicado em TENDÊNCIAS/DEBATES. São Paulo, quinta-feira, 14 de maio de 2009. Disponível em: http://www1.folha.uol.com.br/fsp/opiniao/inde14052009.htm.

* Pós-doutor em Estudos Sociais da Ciência e Tecnologia pela Universidade de Sussex, doutor em Ciências Econômicas pela UNICAMP. Professor Titular no Departamento de Política Científica e Tecnológica da UNICAMP. Endereço eletrônico: rdagnino@ige.unicamp.br.
} 
são as empresas, mas as universidades. Apesar do seu paradoxal esforço, a superioridade coreana é de 30 para 1.

Os críticos dizem que o resultado desse campeonato não depende daquele da ciência e que o crescimento das publicações é simples conseqüência do aumento do número de mestres e doutores. Como as empresas não precisam fazer pesquisa, não os empregam e não patenteiam esse campeonato também está perdido.

O terceiro envolve o Campeonato da Produção, entendido pela comunidade de pesquisa como o penúltimo elo da cadeia linear de inovação que ela usa como modelo para elaborar a política de ciência e tecnologia. Nele, o gol é a participação dos produtos high-tech nas exportações do país. Aqui, a superioridade do país tomado como modelo (Coréia) é de 3 para 1.

Como no Campeonato da Tecnologia, os críticos estão mais interessados no jogo que ocorre no "campo" da empresa, da produção. Eles têm mostrado aos que elaboram a política de C\&T, e que só jogam no "campo" da ciência, que seus campeonatos são de outros esportes. E que o sucesso no Campeonato da Ciência Publicada pode ser bom para quem dele participa, mas não para o que eles alegam ser os "interesses do país".

O quarto questionamento tem a ver com o Campeonato da Tecnologia Social. Nele, o "campo" não é o da empresa, mas o dos movimentos sociais. Aqui, fazer gol é aplicar diretamente nosso potencial de C\&T para o desenvolvimento social sem esperar que ele ocorra por meio das empresas. É lutar para sair da "lanterna" nesse torneio.

Os críticos sabem que isso exige muita criatividade, originalidade e conhecimento. Não há receita de como desenvolver, com os empreendimentos solidários, soluções adequadas do ponto de vista social, técnico e ambiental. Isso que é imprescindível na nossa situação e nunca foi feito antes.

Nesse caso, o poder dos críticos é muito menor. Mas eles estão conseguindo mostrar a seus pares que querem um país mais justo e sustentável que seu campeonato é o mais importante. E que centenas de trabalhos científicos já mostraram que vencê-lo não é conseqüência linear de bons resultados nos campeonatos anteriores.

O fato de não sabermos produzir conhecimento científico e tecnológico compatível com valores morais (e ambientais) e interesses econômicos alternativos nem conceber mecanismos institucionais para fomentá-lo exige uma reorientação da política de C\&T. É injustificável que nosso plano de C\&T aloque menos de $2 \%$ de seus recursos para o seu quarto eixo, "C\&T para o Desenvolvimento Social". 
Depende da capacidade de mobilização e convencimento desses jogadores-críticos que estão entrando em campo para transformar o Campeonato da Ciência Publicada no Campeonato da Tecnologia Social, nossa chance de construir um país melhor. 
